\title{
Preparasi DNA Spesies Colletotrichum sp. dan Spesifitas Sistem Fingerprinting RAPD
}

\author{
Jamsari \\ Laboratorium Bioteknologi dan Pemuliaan Tanaman, Program Studi Pemuliaan Tanaman \\ Jurusan Budidaya Pertanian, Fakultas Pertanian Universitas Andalas Padang \\ Kampus Limau Manis Unand Padang, 25163 Sumatera Barat \\ Diterima 07-01-2008 Disetujui 11-09-2008
}

\begin{abstract}
DNA preparation from C. capsici dan C. gleosporides is important for PCR based analysis of anthracnose causing pathogens. On the other hand, RAPD as one of DNA-based fingerprinting is hindered by its instability and its non specifity problems. For that reason, converting RAPD fragments into other DNA based systems is an alternative to increase its analysis reliability. The study showed that mycelia grown in 2-days liquid culture is appropriate material for DNA preparation especially when combined with Shagai-Maroof protocol as well as Promega Genomic DNA Isolation Kit. The study indicated also that some isolated RAPD-fragments showed its instability character. This was proved by the occurrence of multi different length of fragments after re-amplification of some single RAPD specific fragments.
\end{abstract}

Keywords: C. capsici, C. gleosporides, RAPD- analysis

\section{PENDAHULUAN}

Perkembangan teknik PCR (polymerase chain reaction) membuka peluang pengembangan deteksi dini keberadaan patogen-patogen meskipun mereka masih dalam jumlah populasi yang sangat sedikit sekalipun. Penggunaan PCR sebagai metode dini untuk mendiagnosis kehadiran suatu patogen telah banyak dilaporkan oleh beberapa peneliti (Kim \& Lee 2002; Thomsen \& Jensen, 2002; Schmink et al, 2001) demikian pula aplikasinya untuk identitas spesies telah banyak dilaporkan oleh beberapa peneliti (Mongkolporn \& Dokmaihom 2004; Shaaban et al, 2006; Das et al, 2005);

Salah satu tahapan penting untuk keberhasilan diagnosis berbasis PCR adalah ketersediaan DNA. Genus Colletotrichum merupakan salah satu kelompok jamur berfilamen (filamentous fungi) yang diketahui sulit untuk diisolasi. Beberapa metode preparasi DNA dari genus Colletotrichum telah dedeskripsikan oleh beberapa peneliti seperti Colletotrichum lindemuthianum (Roca et al, 2003) Colletotrichum acutatum (Guerber et al, 2003), Colletotrichum coccodes, C. crassipes, dan C. dematium (Cano et al, 2004). Sayangnya preparasi DNA untuk spesies $C$. capsicibelum pernah dipublikasikan di manapun.

Telp: 0751-72776

Email:ajamsari@yahoo.com
Sistem penanda RAPD merupakan penanda molekuler berbasis informasi DNA yang memanfaatkan keunggulan teknik PCR. Sejak diperkenalkan pertama sekali oleh Williams et al, (1990), sistem penanda ini telah diaplikasikan secara luas untuk berbagai aplikasi dari mulai dari karakterisasi varietas-variets barley, brassica, seledri, bawang, kentang dan tomat (Dweikat et al, 1993) sampai karakterisasi bakteri Lactobacillus fermentum (Hayford et al, 1999). Seiring dengan intensifnya penggunaan sistem marker tersebut, berbagai laporan tentang kelemahan sistem RAPD juga telah banyak dilaporkan (Meunier \& Grimont 1993; Rajput et al, 2006), terutama menyangkut ketidakstabilan dan sensitifitasnya yang sangat besar. Oleh karena itu, upaya konversi sistem berbasis RAPD kedalam sistem lain seperti SCAR, STS telah banyak dilakukan (Xu et al, 2004)

Dalam paper ini akan dideskripsikan upaya penyediaan DNA untuk keperluan analisis berbasis PCR, serta fenomena ketidakspesifikan fragmen yang dihasilkan dari fingerprinting berbasis RAPD.

Kultur Jamur. Sampel sebanyak 20 isolat jamur dikoleksi dari berbagai sentra produksi tanaman cabai yang ada di Sumatera Barat. Hifa jamur dari koleksi isolat-isolat Colletotrichum sp. Yang telah dikoleksi dari berbagai sentra produksi cabai di Propinsi Sumatera Barat dikulturkan dalam media cair PDB (Potatoe 
Dextrose Broth) yang mengandung 10\% Dekstrosa dan ekstrak kentang. Kultur jamur selanjutnya dishaker dengan kecepatan sekitar 120 rpm selama 2 hari. Sebagian dari kultur jamur sebelumnya telah dishaker sampai 7 hari lalu disimpan di dalam $-20^{\circ} \mathrm{C}$.

Isolasi DNA dengan Metode Saghai-Maroof dan Kit Promega. Tahap ini dilakukan dengan tujuan untuk membandingkan tingkat efektifitas dan efisiensi kedua metode isolasi tersebut. Secara ringkas tahap isolasi kedua metode tersebut dapat dideskripsikan sebagai berikut.

Isolasi Protokol (Saghai-Maroof et al, 1994). Sekitar 0,5 g miselia segar dari kultur cair dari masingmasing perlakuan digerus sampai halus. Untuk miselia yang diambil dari kultur dua hari sebelum digerus terlebih dahulu diperlakukan dengan perendaman dalam 100 mM EDTA selama tiga kali dan terakhir dengan akuades. Bubuk gerusan selanjutnya ditambah $1 \mathrm{ml}$ buffer ekstraksi 2x CTAB yang telah dihangatkan terlebih dahulu. Buffer ekstraksi mengandung 2\% CTAB (w/v), 200 mM Tris- $\mathrm{HCl}$ (pH 7,5), 20 mM EDTA dan 1,4 $\mathrm{M} \mathrm{NaCl}$ serta $1 \%(\mathrm{v} / \mathrm{V}) \beta$-Mercaptoethanol yang ditambahkan dalam keadaan segar sebelum Buffer ekstraksi digunakan. Campuran gerusan dan buffer ekstraksi divorteks sampai menjadi homogen. Selanjutnya diinkubasi pada suhu $65^{\circ} \mathrm{C}$ selama minimal 1 jam sambil setiap lima menit digoyanggoyang. Lalu ditambah $500 \mu \mathrm{l}$ campuran $\mathrm{Cl}$ (Chloroform : Isoamyslalkohol = $24: 1$ ) dan dicampur dengan cara membolak-balikkan campuran selama sekitar 10 menit. Setelah itu disentrifus pada 14.000 rpm selama 30 menit. Supernatan yang diperoleh setelah sentrifugasi diambil dan ditransfer ke dalam tabung eppendorf $2 \mathrm{ml}$ steril yang baru dan dilakukan presipitasi dengan isopropanol dingin. Selanjutnya kepada keduanya diinkubasikan pada suhu $-20^{\circ} \mathrm{C}$ selama 2 jam dan dilakukan sentrifusi pada 14.000 rpm selama 2 menit. Supernatan dibuang, pellet dicuci dengan wahing buffer I yang mengandung $10 \mathrm{mM} \mathrm{Na-Acetat} \mathrm{dan} \mathrm{76 \%} \mathrm{(v/v)}$ Ethanol (p.a.), yang dilanjutkan dengan pencucian kedua dengan washing buffer II yang mengandung 200 $\mathrm{mM}$ Ammonium Acetate dan $76 \%$ Ethanol p.a. (v/v). Pellet kemudian dikeringkan dan diencerkan dengan $100 \mu \mathrm{T} \mathrm{TE}$.

Isolasi dengan Protokol Kit Promega (Promega-USA). Isolasi dengan menggunakan protokol Kit isolasi DNA genomik prinsipnya mengikuti prosedur yang telah disarankan oleh produsennya. Secara ringkas prosedur tersebut dilakukan sebagai berikut. Miselia yang telah digiling dicampur dengan $500 \mu \mathrm{l}$ Buffer lisis sel (cell lysis buffer) dan $500 \mu \mathrm{l}$ nucleilysis divorteks sampai merata, lalu diinkubasi selama 5 menit pada suhu $65^{\circ} \mathrm{C}$. Selanjutnya ditambah $100 \mu \mathrm{l}$ larutan presipitasi protein (protein-precipitation solution) dan diinkubasi pada suhu kamar selama 25 menit. Kemudian ditambah kembali $100 \mu$ l larutan presipitasi protein dan diinkubasi pada suhu $-20^{\circ} \mathrm{C}$ selama 15 menit. Dicampur dengan cara membolak-balikkan dan selanjutnya disentrifus pada 14.000 rpm selama 15 menit. Supernatan diambil dan ditambahkan isopropanol serta diinkubasikan pada suhu $-20^{\circ} \mathrm{C}$ selama 2 jam. Selanjutnya disentrifus pada 14.000 rpm, supernatan dibuang dan pellet diproses seperti protokol Saghai-Maroof.

Analisis Elektrophoresis. Untuk mengontrol efektifitas dan keberhasilan isolasi serta pengontrolan produk hasil amplifikasi DNA dengan PCR, maka dilakukan analisis elektrophoresis. Untuk kegiatan ini, digunakan gel agarose dengan konsentrasi sesuai kebutuhan. Untuk mentest hasil isolasi DNA maka digunakan agarose dengan konsentrasi $0,75 \%$, sedangkan untuk analisis hasil restriksi dan produk amplifikasi digunakan agarose dengan konsentrasi antara $1 \%$ sampai $1,5 \%$ tergantung ukuran fragmen yang diperoleh. Elektrophoresis dilakukan pada suatu sistem elektrophoresis yang dilengkapi dengan timer pengatur waktu dan tegangan. Alat elektrophoresis yang digunakan adalah Mupid-Ex (Mupid-ex-Jepang). Tegangan yang digunakan pada umumnya adalah 100 volt DC. Dokumentasi hasil elektrophoresis dilakukan menggunakan Image-Documentation System CS-1 (Cybertech-Jerman).

Amplifikasi DNA dan Fingerprinting RAPD. Sebanyak 25 primer RAPD yang disintesis oleh Cybergene-AB (Swedia) (Tabel 1) telah dicobakan untuk mengamplifikasi DNA hasil isolasi dengan kedua metode sebelumnya. Amplifikasi dilaksanakan dengan menggunakan volume $15 \mu \mathrm{l}$ melalui suatu campuran antara RTG-PCR Bead (LG-USA) dengan 25 ng DNA jamur sebagai template serta $20 \mathrm{pmol}$ masing-masing primer. Reaksi PCR dilakukan dengan menggunakan mesin PCR berkapasitas 48 reaksi $\times 0,2 \mathrm{ml}$ dan 30 reaksi x 0,5 ml (combo block) dari Biometra (BiometraJerman). Reaksi dilaksanakan dengan menggunakan 
kondisi 2 kali loop. Loop pertama terdiri dari denaturasi selama 1 menit yang diikuti dengan annealing $42^{\circ} \mathrm{C}$ selama 5 menit serta ekstensi pada $72^{\circ} \mathrm{C}$ selama 2 menit dalam 1 siklus. Loop kedua menggunakan suhu denaturasi, annealing dan ekstensi yang sama hanya dengan waktu masing-masing 30 detik, 30 detik dan 1 menit berturut-turut selama 45 siklus.

Produk PCR dicek menggunakan teknik elektrophoresis dengan terlebih dahulu mencampurnya dengan loading buffer 10X BPB (Bhromophenol Blue).

Isolasi dan Purifikasi Fragment RAPD Spesifik. Fragmen-fragmen RAPD yang memperlihatkan karakteristik spesifik, dengan arti dapat digunakan sebagai penciri spesifik baik pada spesies $C$. capsici maupun pada $C$. glesoporides ataupun hadir sebagai penciri kedua spesies tersebut diisolasi dari agarose dengan menggunakan teknik pemotongan. Pemotongan dilakukan dengan sangat hati-hati karena harus dilakukan dibawah paparan sinar UV. Pemotongan dilakukan menggunakan skalpel steril dengan hanya mengambil bagian yang mengandung fragmen yang dikehendaki. Fragmen terpilih dimasukkan ke dalam tabung eppendorf $1,5 \mathrm{ml}$ dan dibungkus dengan aluminium foil serta disimpan paling lama seminggu sebelum dilakukan purifikasi. Fragmen diberi label agar tidak tertukar identitasnya. Purifikasi fragmen RAPD dilakukan dengan menggunakan Wizard SV Gel and PCR Clean-up System Kit (Promega-USA) sesuai dengan petunjuk produsen.

Reamplifikasi dan Pengujian Spesifitas Fragmen RAPD Spesifik. Untuk mengevaluasi spesifitas fragmen spesifik yang sudah diisolasi maka dilakukan reamplifikasi. Reamplifikasi dilakukan dengan menggunakan prosedur PCR seperti telah dijelaskan di atas. Fragmen dianggap spesifik apabila hasil pengujian memperlihatkan hanya satu fragmen dengan ukuran yang sama dengan fragmen asal yang digunakan sebagai template. Fragmen tidak spesifik apabila hasil reamplifikasi dengan menggunakan primer asal terhadap fragmen tersebut menghasilkan lebih dari satu fragmen produk PCR dengan ukuran yang berbeda dari ukuran primer semula.

\section{HASIL DAN PEMBAHASAN}

Isolasi DNA. Dari sebanyak 20 sampel isolat yang telah dicoba untuk diisolasi 11 sampel $(55,0 \%)$ berhasil memperlihatkan fragmen DNA setelah dilakukan pengujian dengan menggunakan analisis elektrophoresis. Sedangkan sampel lainnya sebanyak 9 isolat $(45,0 \%)$ tidak memperlihatkan tanda-tanda adanya fragmen DNA yang dihasilkan setelah isolasi. Kalau diperhatikan lebih jauh, kesebelas sampel yang berhasil diisolasi tersebut, jenis sumber material yang dipergunakan keseluruhannya adalah LC-2 yakni kultur cair yang berumur 2 hari. Sedangkan kesembilan sampel yang tidak memberikan DNA dalam kegiatan isolasi keseluruhannya merupakan sampel yang menggunakan jenis material LC-7-F yakni sampel berasal dari kultur cair yang telah berumur 7 hari dan disimpan dalam waktu yang lama di dalam suhu $-20^{\circ} \mathrm{C}$ sebelum diisolasi.

Jika dilihat hubungan antara jenis material dan metode isolasi yang digunakan, secara umum kedua protokol yang digunakan yakni berbasis Saghai-Maroof et al (1984) yang telah dimodifikasi dan protokol dengan menggunakan kit Isolasi dari promega memberikan peluang efisiensi yang baik, meskipun ada satu sampel yang diisolasi dengan menggunakan kit tidak berhasil memberikan fragmen DNA. Ketidakberhasilan tersebut diduga disebabkan hanya oleh kesalahan prosedur isolasi. Keberhasilan kedua prosedur metode isolasi tersebut ternyata berlaku tidak hanya pada isolat spesies $C$. capsici, akan tetapi juga pada isolasi $C$. gleosporides, meskipun dua sampel yang tidak berhasil diisolasi dengan kit merupakan isolat $C$. gleosporides. Dengan demikian, faktor yang paling menentukan keberhasilan dalam isolasi DNA dalam hal ini kelihatannya lebih ditentukan oleh umur jenis material yang digunakan. Hal yang sama memang ditekankan oleh Shagai-Maroof et al, (1984), bahwa kunci utama dalam isolasi menggunakan protokol yang disarankannya adalah penggunaan miselia yang masih muda. Apalagi spesies Colletotrichum sp. merupakanspesies jamur yang tergolong kepada jamur filamen (filamentous fungi). Keberhasilan Isolasi jamur berfilamen pada umumnya sulit dilakukan.

Data hasil elektrophoresis terhadap 10 sampel yang berhasil memperlihatkan DNA menunjukkan konsentrasi yang beragam dari mulai $10 \mathrm{ng} / \mu \mathrm{l}$ sampai $60 \mathrm{ng} / \mu \mathrm{l}$. Efisiensi isolasi menghasilkan total konsentrasi sebesar 1,0 $\mu \mathrm{g}$ sampai $6 \mu \mathrm{g}$ DNA. Jumlah tersebut dianggap mencukupi sebagai material untuk kegiatan analisis berbasis PCR yang akan dilakukan selanjutnya. Bahkan DNA sebanyak $6 \mu \mathrm{g}$ juga masih 
mencukupi untuk analisis DNA berbasis hibridisasi seperti RFLP yang membutuhkan jumlah material ratarata di atas $1 \mu \mathrm{g}$ (Botstein et al, 1980; Jiang et al, 1997; Jamsari 2003).

Jika diperhatikan jenis spesies yang diisolasi, terlihat kenyataan bahwa $C$. capsici menghasilkan konsentrasi DNA yang lebih banyak dibandingkan dengan $C$. gleosporides meskipun jumlah material yang digunakan relatif sama pada awalnya. Hal ini diduga berkaitan dengan tingkat kompleksitas komposisi dan struktur sel yang dimiliki C. gleosporides. C. capsici diduga memiliki struktur dan komposisi fisikokimia yang lebih sederhana dibandingkan dengan $C$. gleosporides. Sayangnya sampai saat ini belum ada publikasi yang melaporkan tentang struktur fisikokimia kedua spesies tersebut. Dari dua protokol isolasi yang digunakan sebenarnya tidak memperlihatkan hasil yang berbeda. Dengan demikian kedua protokol yang digunakan sebenarnya sama-sama memiliki efektifitas yang cukup baik untuk digunakan dalam isolasi jamur $C$. capsici dan C. gleosporides.

Hasil elektrophoresis di atas juga mengindikasikan bahwa kwalitas DNA yang dihasilkan dari proses isolasi di atas memperlihatkan kualitas yang cukup baik. Hal ini dapat ditandai dengan sedikitnya fragmen-fragmen smear di bawah fragmen utama yang berukuran besar (Gambar 1). Fragmen-fragmen smear merupakan kumpulan potongan-potongan DNA pendek yang terbentuk pada saat proses isolasi. Meskipun pada setiap sampel ditemukan adanya indikasi tanda-tanda DNA smear, tetapi proporsi DNA dari fragmen utama masih sangat besar, dengan demikian DNA tersebut tergolong masih baik untuk digunakan pada kegiatan analisis selanjutnya. Hasil tersebut juga didukung oleh data elektrophoresis hasil restriksi dengan menggunakan enzim EcoRI (data tidak ditunjukkan).

Hasil yang diperoleh dari penelitian ini memperlihatkan bahwa metode Saghai-Maroof et al, (1984) merupakan salah satu protokol isolasi yang sesuai untuk digunakan dalam isolasi DNA dari jamur Colletotrichum sp. Aplikasi metode Saghai-Maroof et al, (1984) untuk isolasi DNA telah terbukti memiliki aplikasi yang luas. Selain terbukti dapat digunakan untuk isolasi beberapa spesies jamur seperti Cochliobolus sp., Aternaria sp., dan Fusarium sp., metode tersebut juga telah dipergunakan untuk isolasi DNA tanaman seperti cabai (Capsicum sp.) (Jamsari et al, 2007), asparagus (Asparagus officinalis) (ReamonBüttner et al, 2000; Jamsari 2003), dan tanaman bit gula (Beta vulgaris) (El-Mezawy et al, 2002), bahkan metoda tersebut juga dapat digunakan untuk mengisolasi DNA dari spesies tanaman dengan kandungan senyawa fenolik tinggi seperti Uncaria gambir (Noverta 2007).

Untuk kegiatan analisis tahap selanjutnya maka digunakan 3 sampel dari $C$. capsici yakni S5, P16, dan A6 dan 3 sampel DNA dari $C$. gleosporides yakni sampel dengan kode PS11, PS17 dan PS42. Hal ini dilakukan dengan mempertimbangan ketersediaan DNA dan kualitas yang dimiliki oleh masing-masing sampel.

Analisis Variabilitas dengan Marker Molekuler. Analisis variabilitas diantara spesies $C$. capsicidan $C$. gleosporides disidik dengan menggunakan teknik finger printing DNA berbasis RAPD (Random Amplified Polymorhic DNA) (Williams et al, 1990). Tahap awal dalam kegiatan analisis ini adalah melakukan amplifikasi menggunakan DNA jamur yang dipool. Pool terdiri dari campuran DNA dari isolate-isolat $C$. capsici dan DNA isolate-isolat $C$. gleosporides, di mana dengan demikian pool terdiri dari 6 DNA isolat yang berbeda. Kelompok C. capsici terdiri dari DNA 3 isolat yakni isolate nomor PS11, PS17, dan PS42. Sedangkan kelompok C. gleosporides terdiri dari DNA isolat-isolat nomor A6, P16, dan S5. Konsentrasi awal yang digunakan untuk pembentukan pool adalah $50 \mathrm{ng} / \mu \mathrm{l}$. Volume larutan DNA yang dicampurkan dari masingmasing isolat adalah $50 \mu$ l, sehingga pada akhirnya setiap pool diperoleh $300 \mu$ l larutan DNA dengan konsentrasi pool sebesar $50 \mathrm{ng} / \mu \mathrm{l}$ dan konsentrasi DNA masing-masing isolat di dalam pool adalah sebesar 8,3 $\mathrm{ng} / \mu \mathrm{l}$. Konsentrasi tersebut cukup tinggi untuk analisis PCR berbasis RAPD. Beberapa peneliti menggunakan konsentrasi template yang berbeda untuk analisis RAPD. Di Sitilio et al, (1998), menggunakan konsentrasi template total 12,5 ng untuk mengamplifikasi DNA Silene latifolia, sedangkan Zahner et al, (1999), menggunakan konsentrasi total $25 \mathrm{ng}$ (5 x $5 \mathrm{ng} / \mu \mathrm{l})$ untuk analisis RAPD terhadap Brevibacillus laterosporus demikian pula Lal Meena et al, (2005) menggunakan konsentrasi total 25 ng untuk mengamplifikasi Tospovirus dalam analisis RAPDnya. Dengan demikian untuk analisis PCR nantinya dapat digunakan minimal $2 \mu$ l template DNA sehingga peluang 
untuk mendapatkan fragmen yang diharapkan akan lebih besar.

Dari total 25 primer RAPD yang digunakan, sebanyak 21 primer dapat menghasilkan fragmen produk PCR dengan jelas pada pool yang diuji (Gambar 3). Sementara empat primer lainnya hanya menghasilkan produk PCR yang smear, dan sulit membedakan antara fragmen satu dengan lainnya dalam satu line sehingga ditetapkan tidak akan dipergunakan pada analisis tahap berikutnya. Total fragmen PCR yang dihasilkan dari ke 21 primer yang diuji (Tabel 1) berjumlah 116 fragmen dengan kisaran antara 3 fragmen yang paling sedikit dan 9 fragmen yang paling banyak. Dengan demikian rata-rata jumlah fragmen yang dihasilkan adalah 5,5 fragmen per primer.

Jumlah fragmen yang diperoleh hampir sama dengan hasil analisis RAPD yang diperoleh pada spesies Brevibacillus laterosporus (Zahner et al, 1999). Namun jumlah fragmen sebanyak itu tergolong sedikit jika dibandingkan dengan jumlah fragmen RAPD yang dihasilkan oleh Adetula (2006) dengan rata-rata 11 fragmen pada spesies (Capsicum sp.) Pada spesies tomat (Lycopersicum sp.) Rajput et al, 2006 mendapatkan jumlah fragmen rata 20 per primer. Namun demikian peneliti lain dengan analisis RAPD juga pada spesies Capsicum sp. juga mendapatkan rata-rata 5 fragmen per primer (Rodriguez et al, 1999).

Banyak sedikitnya jumlah fragmen RAPD yang diperoleh berkaitan dengan karakteristik genom yang dimiliki oleh spesies. Pada spesies dimana jumlah fragmen yang dihasilkan hanya sedikit, berarti titik ikatan antara primer dengan templat DNAnya lebih sedikit sehingga jumlah fragmen teramplifikasi menjadi sedikit. Kondisi sebaliknya terjadi pada spesies yang mampu menghasilkan jumlah fragmen lebih banyak. Meskipun kondisi tersebut terjadi juga variasi antara primer yang digunakan. Primer OPN16 contohnya mampu menghasilkan fragmen sampai 9 buah. Itu artinya, bahwa posisi binding site yang dapat teramplifikasi memiliki jumlah yang lebih banyak.

Analisis Primer RAPD pada Kelompok Spesies Spesifik. Sebagaimana telah disebutkan di atas, bahwa hasil analisis amplifikasi dengan templet pool DNA menghasilkan 21 primer yang mampu menghasilkan fragmen RAPD. Akan tetapi dalam pengujian pada level individu hanya digunakan 10 primer (Tabel 1). Pemilihan kesepuluh primer tersebut didasarkan atas dua kriteria yakni jumlah fragmen yang dihasilkan dan kejelasan

Tabel 1. Daftar isolat yang digunakan untuk isolasi DNA

\begin{tabular}{|c|c|c|c|c|c|c|}
\hline No & $\begin{array}{l}\text { Kode } \\
\text { Isolat }\end{array}$ & Spesies & $\begin{array}{c}\text { Jenis } \\
\text { Material }\end{array}$ & Metode Isolasi & $\begin{array}{l}\text { Kons. DNA } \\
(\mathrm{ng} / \mu \mathrm{l}) ; \mu \mathrm{g}\end{array}$ & Asal Isolat \\
\hline 1. & $A 6^{*}$ & C. capsici & LC-2 & SM & $50 ; 5$ & Kab. Agam \\
\hline 3. & C1 & C. capsici & LC-2 & $\mathrm{KP}$ & $60 ; 6$ & Kab. Agam \\
\hline 4. & D1-9 & C. capsici & LC-2 & SM & $55 ; 5,5$ & Kota Padang \\
\hline 7. & PS11* & C. gleosporides & LC-2 & $\mathrm{KP}$ & $10 ; 1$ & Kab. Pasaman \\
\hline 8. & $\mathrm{PS} 17^{*}$ & C. gleosporides & LC-2 & $\mathrm{KP}$ & $10 ; 1$ & Kab. Pasaman \\
\hline 9. & PS19 & C. gleosporides & LC-2 & $\mathrm{KP}$ & - ; - & Kab. Pasaman \\
\hline 10. & PS42* & C. gleosporides & LC-2 & $\mathrm{KP}$ & $10 ; 1$ & Kab. Pasaman \\
\hline 15. & S20 & C. gleosporides & LC-7-F & SM & $-;-$ & Kab. Solok \\
\hline 16. & $\mathrm{~S} 25$ & C. gleosporides & LC-7-F & $\mathrm{KP}$ & $-;-$ & Kab. Solok \\
\hline 17. & S3 & C. capsici & LC-7-F & $\mathrm{KP}$ & $-;-$ & Kab. Solok \\
\hline 18. & S4 & C. gleosporides & LC-7-F & $\mathrm{KP}$ & $-;-$ & Kab. Solok \\
\hline 19. & PS17 & C. gleosporides & LC-7-F & SM & $-;-$ & Pasaman Barat \\
\hline 20. & PS18 & C. gleosporides & LC-7-F & SM & $-;-$ & Pasaman Barat \\
\hline 18. & S4A & C. gleosporides & LC-7-F & SM & $-;-$ & Kab. Solok \\
\hline 19. & S5 & C. gleosporides & LC-7-F & SM & - ; - & Kab. Solok \\
\hline 20. & $\mathrm{~S} 5^{*}$ & C. capsici & LC-2 & SM & $50 ; 5$ & Kab. Pasaman \\
\hline
\end{tabular}

SP : Protokol berbasis Saghai-Maroof et al, (1984)

KP : Protokol menggunakan kit dari Promega (Promega-USA). 
fragmen yang diperoleh. Primer yang menghasilkan fragmen lebih banyak menjadi prioritas untuk digunakan. Namur demikian apabila fragmen-fragmen yang dihasilkan tersebut kurang jelas untuk dibedakan, maka primer tersebut menjadi prioritas berikutnya.

Analisis pada tahap ini menggunakan DNA individu tiga isolat dari masing-masing spesies. Dengan demikian jumlah isolat yang digunakan berjumlah 6 , yakni tiga dari $C$. capsicidan tiga dari $C$. gleosporides. Keenam isolat tersebut merupakan isolat-isolat yang digunakan sebagai penyusun DNA pool sebelumnya. Analisis pada tahap ini menggunakan DNA individu tiga isolat dari masing-masing spesies. Dengan demikian jumlah isolat yang digunakan berjumlah 6 , yakni tiga dari $C$. capsici dan tiga dari $C$. gleosporides. Keenam isolat tersebut merupakan isolat-isolat yang digunakan sebagai penyusun DNA pool sebelumnya.

Dari 10 primer yang diuji, 4 primer (OPA-02, OPK04, OPN-15 dan OPW-01) memperlihatkan adanya minimal 1 fragmen spesifik pada $C$. gleosporides, 3 primer (OPW-02, OPW-14 dan OPY-13) menghasilkan minimal 1 fragmen yang hanya diperlihatkan oleh $C$. capsicisedangkan 1 primer (OPN-16) menghasilkan 1 fragmen umum dari kedua spesies tersebut (Tabel2).

Tabel 2. Daftar Primer yang telah diuji dengan pool C. capsici dan C. gleosporides.

\begin{tabular}{|c|c|c|c|c|c|c|c|}
\hline No & Kode Primer & Hasil & Jumlah fragmen & No & Kode Primer & Hasil & $\begin{array}{l}\text { Jumlah } \\
\text { fragmen }\end{array}$ \\
\hline 1. & OPA-02* & OK & 7 & 13. & OPN-16* & OK & 9 \\
\hline 3. & OPA-13 & smear & - & 15. & OPW-01* & OK & 7 \\
\hline 4. & OPC-02 & smear & - & 16. & OPW-02* & OK & 5 \\
\hline 7. & OPE-18 & OK & 5 & 19. & OPW-14* & OK & 6 \\
\hline 8. & OPK-04* & OK & 7 & 20. & OPW-19 & OK & 5 \\
\hline 9. & OPK-04 & OK & 6 & 21. & OPY-08 & OK & 4 \\
\hline 10. & OPN-06* & OK & 7 & 22. & OPY-09 & Smear & - \\
\hline
\end{tabular}

Tabel 3. Hasil seleksi primer pada level individu untuk melihat spesifitas pada masing-masing spesies. Posisi fragmen dinyatakan pada panjang fragmen sesuai penunjukan menurut size marker (Finnzyme-Finlandia).

\begin{tabular}{|c|c|c|c|c|}
\hline No & Nama Primer & Hasil & $\begin{array}{l}\text { Jumlah/Posisi } \\
\text { Fragmen (bp) }\end{array}$ & Kesimpulan \\
\hline 1. & OPA-02 & $\begin{array}{l}\text { Kandidat produk spesifik di kelompok } C \text {. } \\
\text { gleosporides tidak ada fragmen spesifik di } \\
\text { kelompok } C \text {. capsici }\end{array}$ & $1 / 1078$ & Potensi spesifik $\mathrm{Cg}$ \\
\hline 2. & OPE-14 & Tidak ada produk spesisifik pada Cg maupun Cc & - & Dihentikan \\
\hline 3. & OPK-04 & $\begin{array}{l}\text { Kandidat produk spesifik di kelompok } C \text {. } \\
\text { gleosporides tidak ada fragmen spesifik di } \\
\text { kelompok } C \text {. capsici }\end{array}$ & $1 / 1353$ & Potensi spesifik $\mathrm{Cg}$ \\
\hline 4. & OPN-06 & Produk PCR tidak jelas, fragmen smear & - & Dihentikan \\
\hline 5. & OPN-15 & $\begin{array}{l}\text { Kandidat produk spesifik di kelompok } C \text {. } \\
\text { gleosporides tidak ada fragmen spesifik di } \\
\text { kelompok } C \text {. capsici }\end{array}$ & 2/ 1078; 750 & Potensi spesifik $\mathrm{Cg}$ \\
\hline 6. & OPN-16 & $\begin{array}{l}\text { Produk hanya ada pada PS11 }(\mathrm{Cg}) \text { dan } \mathrm{A} 6(\mathrm{Cc}) \text {, } \\
\text { tidak ada fragmen pada isolat yang lain }\end{array}$ & $1 / 603$ & $\begin{array}{l}\text { Fragmen umum untuk } \\
\mathrm{Cg} \text { dan } \mathrm{Cc}\end{array}$ \\
\hline 7. & OPW-01 & $\begin{array}{l}\text { Kandidat produk spesifik di kelompok } C \text {. } \\
\text { gleosporides tidak ada fragmen spesifik di } \\
\text { kelompok C. capsici }\end{array}$ & $2 / 1500 ; 603$ & Potensi spesifik Cg \\
\hline 8. & OPW-02 & $\begin{array}{l}\text { Produk Ok pada PS11, A6 dan P16, smear pada } \\
\text { PS17 dan P42. Sulit membedakan antara fragmen } \\
\text { spesifik pada masing-masing kelompok, tapi ada } \\
\text { produk jelas pada Cc }\end{array}$ & $1 / 603$ & Potensi spesifik Cc \\
\hline 9. & OPW-14 & Kandidat produk spesifik di kelompok Cc & $1 / 1500$ & Potensi spesifik Cc \\
\hline 10. & OPY-13 & Kandidat produk spesifik di kelompok Cc & $1 / 700$ & Potensi spesifik Cc \\
\hline
\end{tabular}




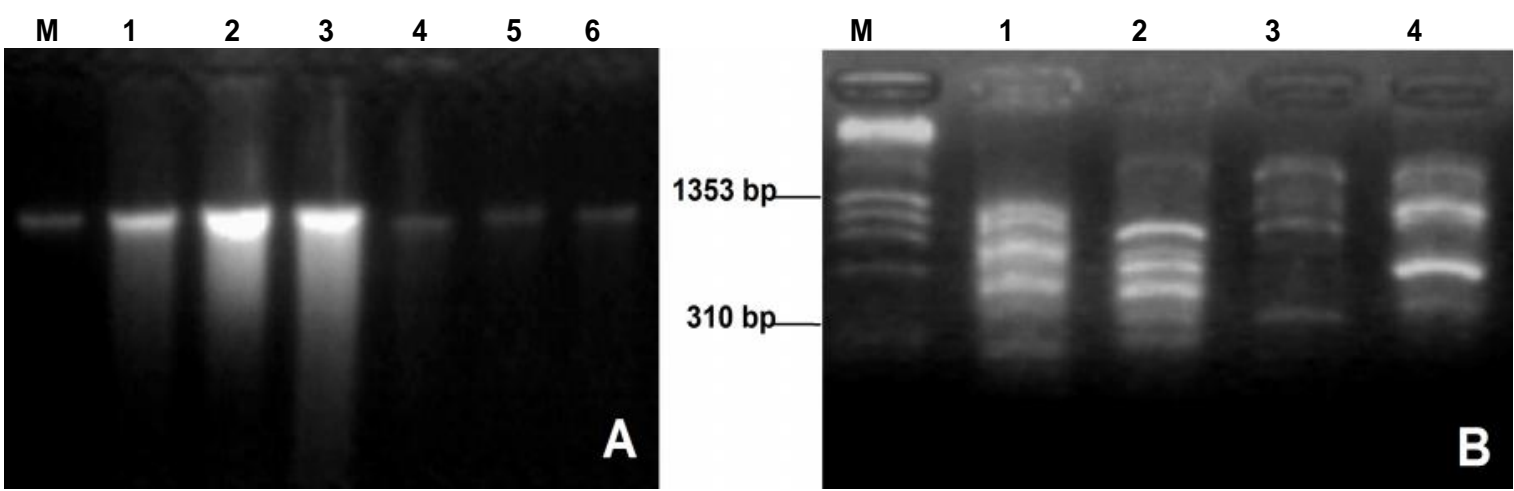

Gambar 1. Panel A: hasil elektrophoresis DNA jamur yang diisolasi dengan menggunakan miselia yang diperoleh dari kultur cair berumur 2 hari. Sampel nomor 1-3 adalah Colletotrichum capsici dan nomor 4-6 adalah Colletotrichum gleosporides. $\lambda=$ DNA lambda $100 \mathrm{ng}$. Panel B: Fragmen-fragmen PCR hasil amplifikasi DNA pool dengan primer yang berbeda. Ukuran fragmen ditunjukkan oleh angka disebelah kiri gambar dalam satuan bp (pasangan basa). $1=$ primer OPW02, $2=$ primer OPW01, 3 = primer OPE08 dan 4 = primer OPN15. $\mathrm{M}=$ size marker (Finnzym, Finlandia).

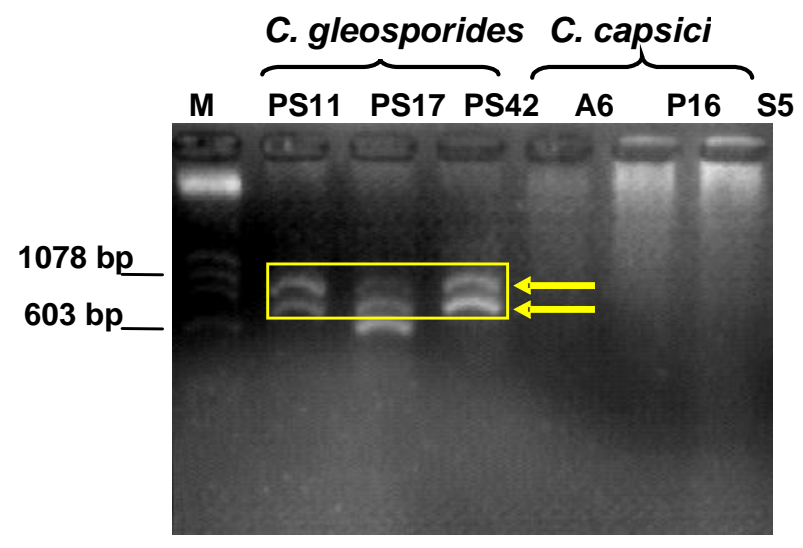

OPN-15-Cg

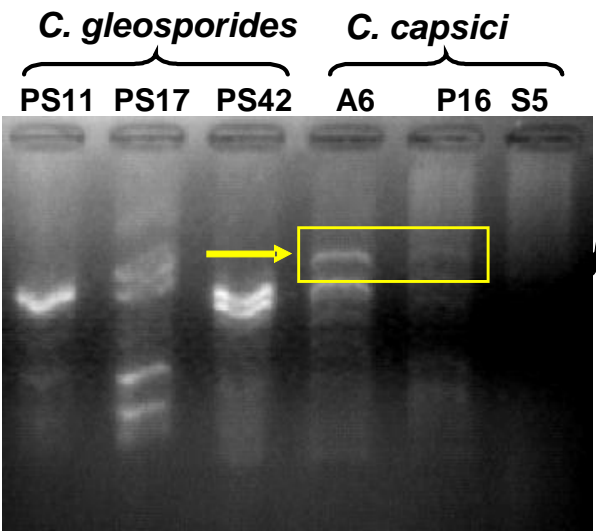

OPW -14-Cc

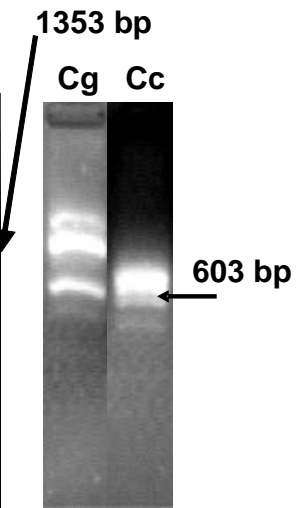

OPN16-Cg/Cc

Gambar 2. Penampilan produk PCR hasil amplifikasi primer terpilih dengan individu isolat dalam kelompok spesies. Ukuran fragmen diperlihatkan oleh anak panah.

P11

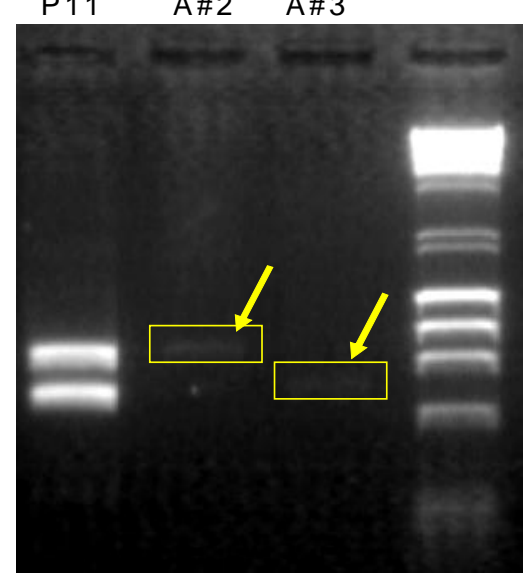

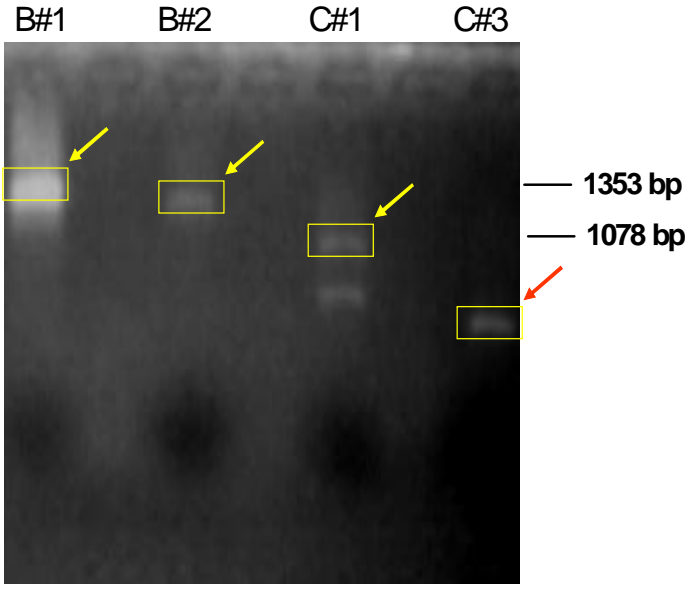

Gambar 3. Produk PCR hasil reamplifikasi fragmen terisolasi dengan primer asalnya. Panel A, reamplifikasi fragmen $A \# 2$ dan $A \# 3$ menggunakan primer OPN15, P11 adalah DNA jamur semula. Panel B reamplifikasi fragmen B\#1 dan B\#2 dengan primer OPK04 dan selanjutnya fragmen C\#1 dan C\#3 dengan primer OPW14. Ukuran fragmen ditunjukkan oleh skala angka yang tertera disebelah kanan. 
Dua primer yakni primer OPE-14 dan OPN-06 tidak menghasilkan produk yang spesifik pada kedua kelompok spesies ataupun menghasilkan produk fragmen yang smear. Kedua primer tersebut akhirnya dikeluarkan dari prosedur tahap purifikasi selanjutnya.

Purifikasi dan Reamplifikasi Fragmen RAPD Spesifik. Purifikasi fragmen RAPD diawali dengan melakukan amplifikasi perwakilan isolat masing-masing spesies. Untuk spesies C. gleosporides digunakan isolat PS11 sedangkan untuk spesies $\mathrm{C}$. capsici digunakan isolat A6. Reaksi amplifikasi dilakukan dengan tiga kali ulangan. Fragmen spesifik yang telah dilokalisasi sebelumnya selanjutnya dipotong dari gel dan dipurifikasi menggunakan Wizard SV Gel and PCR Clean-up system (Promega-USA) (lihat Bahan dan Metode). Pada tahap awal purifikasi dilakukan dari fragmen primer OPN15, OPK04 dan OPW14. Template untuk OPN15 dan OPK04 adalah PS11 sedangkan template DNA untuk OPW14 adalah A6. Untuk membuktikan bahwa fragmen yang diisolasi adalah benar-benar merupakan fragmen tunggal, maka dilakukan pengujian dengan melakukan reamplifikasi terhadap fragmen yang telah dipurifikasi.

Hasil reamplifikasi fragmen A\#1 dengan primer OPN15 menghasilkan empat fragmen dengan ukuran sekitar 1400 bp, 900 bp, 750 bp dan 450 bp (Gambar 2). Padahal ukuran fragmen yang digunakan sebagai templet asalnya berukuran $1400 \mathrm{bp}$. Denga demikian ada 3 fragmen tambahan yang hadir yang sebenarnya tidak dikehendaki. Reamplifikasi fragmen C\#2 yang sebenarnya berukuran 750 bp dengan primer OPW14 menghasilkan dua fragmen dengan ukuran sekitar 500 dan 310. Dengan demikian ukuran yang diperoleh lebih kecil dari ukuran fragmen asalnya. Reamplifikasi juga dilakukan terhadap fragmen-fragmen RAPD lain yang telah diisolasi dari gel. Hasil reamplifikasi fragmen A\#2 (900 bp) dan A\#3 (750 bp) dengan primer OPN15 terbukti memberikan hasil stabil. Kedua fragmen tersebut kembali menghasilkan fragmen dengan ukuran yang sama dengan templatenya. Fragmen C\#1 menghasilkan dua fragmen dengan ukuran $1078 \mathrm{bp}$ dan 500 bp sedangkan panjang fragmen asalnya sekitar 1078 bp. Sementara fragmen $\mathrm{C \# 3}$ yang diidentifikasi memiliki panjang sekitar 500 bp menghasilkan fragmen dengan panjang hanya sekitar $310 \mathrm{bp}$, yang berarti lebih pendek dari fragmen asalnya. Cukup sulit untuk menjelaskan fenomena ini tersebut
Kemungkinan fragmen yang terbentuk pada tahap awal amplifikasi adalah fragmen yang masih memiliki primer internal binding site. Hal tersebut dimungkinkan karena penyatuan primer di sepanjang templet DNA genomik bersifat random/acak. Tambahan lagi, penyatuan mereka pada saat annealing terjadi pada suasana yang saling berkompetisi. Kompetisi terjadi tidak hanya pada saat proses annealing, akan tetapi lama waktu yang diset selama proses annealing dan ekstensi turut memperbesar tingkat pengacakan peluang penempelan primer dan panjang primer yang pada akhirnya akan terbentuk. Dengan demikian hasil akhir pada saat pembentukan fragmen bukanlah merupakan fragmen unik.

Didukung oleh bukti di atas maka satu hal yang dapat disimpulkan, adalah bahwa fragmen RAPD yang diisolasi terbukti bukan seluruhnya merupakan fragmen tunggal yang spesifik, sehingga pada saat reamplifikasi diperoleh produk dengan ukuran yang berbeda-beda. Ketidakstabilan produk RAPD sebenarnya memang telah dilaporkan oleh beberapa peneliti sebelumnya (Meunier \& Grimont 1993; Rajput et al, 2006). Banyak faktor seperti rasio templet DNA dan primer, konsentrasi ion $\mathrm{Mg}$ dan Taq-Polymerase yang digunakan dan bahkan jenis mesin PCR yang dipakai (Yu \& Paul 1992). Bahkan Vos et al, (1995) dan MacPherson et al, (1993) menyatakan, meskipun RAPD tidak sensitif terhadap konsentrasi templet yang digunakan, tetapi apabila templet DNA yang digunakan terlalu banyak juga akan memberikan hasil yang berbeda-beda.

\section{KESIMPULAN}

Dari kegiatan yang telah dilakukan maka dapat ditarik kesimpulan bahwa protokol Saghai-Maroof et al, (1994) dan Protokol Kit dari Promega dapat digunakan untuk preparasi DNA dari spesies C. capsici dan C. gleosporides. Material paling baik yang dapat digunakan untuk keperluan preparasi DNA spesies $C$. capsicidan C. gleosporides adalah miselia yang dihasilkan dari kultur cair berumur 2 hari. Pengujian reamplifikasi beberapa fragmen RAPD spesifik yang telah diisolasi dan dipurifikasi dari matriks agarnya memperlihatkan bukti yang beragam tentang spesifitas fragmen RAPD. $\mathrm{Hal}$ ini dibuktikan dengan dihasilkannya beberapa fragmen dengan ukuran berbeda dari satu fragmen berukuran tunggal. Bukti ini mengisyaratkan perlunya 
kehati-hatian dalam menggunakan fragmen RAPD untuk kegiatan sekuensing langsung.

\section{UCAPAN TERIMAKASIH}

Sebagian dari penelitian ini dibiayai oleh Dirjen Dikti (DP2M) melalui skim penelitian Hibah Bersaing dengan nomor kontrak: 023/SP3/PP/DP2M/II/2007. Ucapan terimakasih disampaikan kepada Darnetty, Helni Lalan dan Selvi Elvia yang telah membantu dalam penyiapan isolat.

\section{DAFTAR PUSTAKA}

Adetula, O.A. 2006. Genetic diversity of capsicum using Random Amplified Polymorphic DNAs. African Journal of Biotechnology 5: 120-122.

Botstein, D., White, R. L., Skolnick, M., Davies, R. W. 1980 Construction of a genetic map in man using restriction fragment lenght polymorphisms. Am. J. Hum. Genet 32: 314 331.

Cano, J., Guarro,J. and Gene, J. 2004. Molecular and morphological identification of colletotrichum species of clinical interest. Journal of Clinical Microbiology, 42: 24502454

Das, M., Bhattacharya, S. and Pal, A. 2005. Generation and characterization of SCARs by cloning and sequencing of RAPD Products: A STRATEGY FOR SPECIES-SPECIFIC MARKER DEVELOPMENT IN BAMBOO. Annals of Botany 95: 835-841

Dweikat I, Mackerzie S, Levy M, Ohm H. 1993. Pedigree assessment using RAPD-DGGE in cereal crop species. Theor. Appl. Gene 85:497-505.

El-Mezawy, A. 2000. Fine mapping of the bolting gene from sugar beet (Beta vulgaris L.) with molecular markers. Dissertation. Germany: Christian Albrechts Universität zu Kiel.

Guerber, J.C, Liu, B., Correll. J.C. 2003. Characterization of diversity in Colletotrichum acutatum sensu lato by sequence analysis of two gene introns, mtDNA and intron RFLPs, and mating compatibility. Mycologia 95: 872-895.

Hayford, A.E. Petersen, A., Vogensen, F., and Jakobsen, M. 1999. Use of conserved Randomly Amplified Polymorphic DNA (RAPD) Fragments and RAPD Pattern for characterization of Lactobacillus fermentum in Ghanaian fermented maize dough. Appl Environ Microbiol 65: 32133221

Jamsari, 2003. Construction of high-density genetic and physical maps around the sex gene $M$ of Asparagus officinalis $L$. Dissertation. Germany: Christian Albrechts Universität zu Kiel.

Jamsari, Darusalam, R., Syahlena, M. Syaputra, R., Darnetty, Putri, N.E. 2007. Seleksi primer RAPD dan studi kekerabatan capsicum sp. Koleksi Dari Sumatera Barat. Aktaagrosia (in Press)

Jiang, C., Lewis, M. E., Sink, K. C. 1997. Combined RAPD and RFLP molecular linkage map of asparagus. Genome 40: 6976.

Kim, K.S., and Lee, Y.S. 2001. Selection of RAPD markers for phytophthora infestans and PCR detection of phytophthora
Preparasi DNA spesies Colletotrichum $s p$.

infestans from potatoes. The Journal of Microbiology 126132

MacPherson, J.M., Eckstein, P.E., Scoles, G.J., Gajadhar, A.A. 1993. Variability of the random amplified polymorphic DNA assay among thermal cyclers, and effects of primer and DNA concentration. Mol Cell Probes 7: 293-299.

Meunier, J.R, Grimont, P.A. 1993. Factors affecting reproducibility of random amplified polymorphic DNA fingerprinting. Res. Microbiol 144: 373-379.

Mongkolporn, O., Dokmaihom, Y. 2004. Genetic purity test of F1 hybrid Capsicum using molecular analysis. The Journal of Horticultural Science and Biotechnology 79: 449-451

Noverta, A. 2007. Optimasi Isolasi DNA Tanaman Gambir (Uncaria gambir Roxb) dan Seleksi Primer RAPD (Random Amplified Polymorphic DNA). Skripsi Sarjana Pertanian. Padang Fakultas Pertanian Unand

Rajput, S.G., Wable, K.J., Sharma, K.M., Kubde, P.D. and Mulay, S.A. 2006. Reproducibility testing of RAPD and SSR markers in Tomato. African Journal of Biotechnology 5: 108 112.

Reamon-Büttner, S. M., Jung, C. 2000. AFLP-derived STS markers for the identification of sex in Asparagus officinalis L. Theor Appl Genet 100: 432-438.

Roca, M.G. Davide, L.C., Wheals, A.E. 2003. Template Preparation for Rapid PCR in Colletotrichum lindemuthianum. Brazillian Journal of Microbiology 34: 8-12.

Saghai-Maroof, M.A.; Soliman, K.M.; Jorgensen, R.A.; Allard, R.W. 1984. Ribosomal DNA spacer-length polymorphisms in Barley: Mendelian inheritance, chromosomal location and population dynamics. Proc Natl Acad Sci USA 81: 8014-8018

Schmink, S., Reeves, M.W, Plikaytis, B., and Popovic. T. 2001. Random Amplified Polymorphic DNA assay as a rapid tool in screening for neisseria meningitidis serogroup $C$ isolates of electrophoretic type 24. Journal of Clinical Microbiology 39: 1622-1625

Shaaban, E.A., Abd-El-Aal, S.K.H., Zaied, N.S., and Rizkalla, A.A. 2006. Assessment of genetic variability on some orange accessions uUsing RAPD-DNA markers. Research Journal of Agriculture and Biological Sciences 2: 564-570, 2006

Thomsen, L., and Jensen, A.B. 2002. Application of nestedPCR technique to resting spores from the entomophthora muscae species complex: implications for analyses of hostpathogen population interactions. Mycologia, 94: 794802

Vos, P., Hogers, R., Bleeker, M., Reijans, M., van de Lee, T., Hornes, M., Fritjters, A., Pot., J., Peleman, J., Kuiper, M., Zabeau, M. 1995. AFLP: A new technique for DNA fingerprinting. Nucl Acids Res 23: 4407-4414

Williams, J.G.K., Kubelick, A.R., Livak, K.J., Rafalski, J.A., Tingey, S.V. 1990. DNA Polymorphisms Amplified by Arbitrary Primers are Useful as Genetic Markers. Nucleic acids Res. 18:6531-6535

Xu, W.J, Wang, B.W and Cui, K.M. 2004. RAPD and SCAR markers linked to sex determination in eucommia ulmoides oliv. Euphytica 136: 233-238.

Yu, K., K.P. Pauls. 1992. Optimization of the PCR program for RAPD analysis. Nucl. Acids Res. 20: 2606.

Zahner, V., Rabinovitch, L, Suffys, P. and H. Momen. 1999. Genotypic Diversity among Brevibacillus laterosporus Strains. Applied and Environemtal Microbiology 65: 51825185 
